\title{
Aspergillus flavus NRRL 35739, a Poor Biocontrol Agent, May Have Increased Relative Expression of Stress Response Genes
}

\author{
Kayla K. Pennerman ${ }^{1}(\mathbb{D})$, Guohua Yin ${ }^{1}(\mathbb{D})$, Joan W. Bennett ${ }^{1}(\mathbb{D})$ and Sui-Sheng T. Hua ${ }^{2, *(D)}$ \\ 1 Department of Plant Biology, Rutgers University, The State University of New Jersey, New Brunswick, \\ NJ 08901, USA; kkpennerman@gmail.com (K.K.P.); guohuayin1997@gmail.com (G.Y.); \\ profmycogirl@yahoo.com (J.W.B.) \\ 2 Foodborne Toxin Detection and Prevention Research, United States Department of Agriculture, \\ Agricultural Research Service, Albany, CA 94710, USA \\ * Correspondence: sylvia.hua@ars.usda.gov
}

Received: 4 May 2019; Accepted: 18 June 2019; Published: 20 June 2019

\begin{abstract}
Biocontrol of the mycotoxin aflatoxin utilizes non-aflatoxigenic strains of Aspergillus flavus, which have variable success rates as biocontrol agents. One non-aflatoxigenic strain, NRRL 35739, is a notably poor biocontrol agent. Its growth in artificial cultures and on peanut kernels was found to be slower than that of two aflatoxigenic strains, and NRRL 35739 exhibited less sporulation when grown on peanuts. The non-aflatoxigenic strain did not greatly prevent aflatoxin accumulation. Comparison of the transcriptomes of aflatoxigenic and non-aflatoxigenic A. flavus strains AF36, AF70, NRRL 3357, NRRL 35739, and WRRL 1519 indicated that strain NRRL 35739 had increased relative expression of six heat shock and stress response proteins, with the genes having relative read counts in NRRL 35739 that were 25 to 410 times more than in the other four strains. These preliminary findings tracked with current thought that aflatoxin biocontrol efficacy is related to the ability of a non-aflatoxigenic strain to out-compete aflatoxigenic ones. The slower growth of NRRL 35739 might be due to lower stress tolerance or overexpression of stress response(s). Further study of NRRL 35739 is needed to refine our understanding of the genetic basis of competitiveness among A. flavus strains.
\end{abstract}

Keywords: Aspergillus flavus; aflatoxin biocontrol; comparative transcriptomics; abiotic stress

\section{Introduction}

Aflatoxins are highly carcinogenic mycotoxins that present major worldwide economic and health challenges [1-4]. The filamentous fungus Aspergillus flavus is the most common cause of aflatoxin contamination of foodstuffs and animal feeds. Field application of a non-aflatoxigenic strain of $A$. flavus is often used as a biocontrol strategy to reduce aflatoxin accumulation $[5,6]$. These non-aflatoxigenic strains lack the ability to produce aflatoxins due to disruptions in the aflatoxin biosynthesis gene cluster [7-9]. Before a non-aflatoxigenic strain is used as a biocontrol agent, it is helpful to verify that the strain does not have or express genes required for aflatoxin production. Most non-aflatoxigenic strains have deletions that fall into one of eight patterns, named $\mathrm{A}$ to $\mathrm{H}$, which can be easily determined with traditional PCR or genomic sequencing [7]. For example, WRRL 1519 exhibits pattern E deletion, lacking the first half of the gene cluster (genes aflF to aflE) [10]. NRRL 21882 (Afla-Guard) has the largest deletion pattern, $\mathrm{H}$ [7]. However, not every non-aflatoxigenic strain shares one of these deletion patterns. For example, the commercial biocontrol agents NRRL 30797 and NRRL 18543 have just a few substitutions and/or deletions in the aflatoxin biosynthesis gene cluster [7,11]. Further, a new Korean strain of Aspergillus oryzae that is highly effective in reducing aflatoxin contamination has deletions throughout the cluster [12]. 
Non-aflatoxigenic A. flavus strains vary in how effective they are in preventing aflatoxin accumulation when grown in the presence of toxigenic strains. Commercially available strains tend to be strong biocontrol agents, but other, less-effective, strains also exist [5,13,14]. Most reports of new non-aflatoxigenic strains skew towards identifying and studying the biocontrol agents with greater potential that many researchers believe prevent aflatoxin accumulation by out-competing aflatoxigenic strains [15-17]. Assayed visually, $80 \%$ of the fluorescently labeled aflatoxigenic $A$. flavus AF70 is suppressed when grown in corn kernels and co-inoculated with the non-aflatoxigenic NRRL 18543 [15]. Co-inoculation of two aflatoxigenic strains also results in lower aflatoxin yields than expected, suggesting that the inability of a given aflatoxigenic strain to create a sufficient mycelial network contributes to biocontrol effectiveness $[18,19]$. A similar effect is seen in apples inoculated with two strains of toxigenic Penicilium expansum in the same wound; the resulting levels of patulin decrease [20]. Another relevant hypothesis states that mycotoxin production is a mechanism to help alleviate oxidative stress $[16,17,21,22]$. Stronger biocontrol agents may be particularly good at enduring oxidative stress [16].

Omics technologies help decrypt the natural variation of these biocontrol agents while yielding abundant data with frequently ambiguous results [23-27]. Investigating a weak A. flavus biocontrol agent would help to reduce background noise in these data and help pinpoint stronger signals that contribute to biocontrol efficacy. To this end, we have investigated A. flavus NRRL 35739 (also known as strain NPL TX13-5), an exceptionally poor biocontrol agent with pattern E deletion [7,26]. Despite being non-aflatoxigenic, this strain does not significantly reduce aflatoxin accumulation when co-inoculated with several aflatoxigenic strains on peanut. More perplexingly, in some instances, the strain even increases toxin production [26]. It was hypothesized that NRRL 35739 is a poor biocontrol agent due to a lack of reduced expression of redox genes that could be revealed via comparative transcriptomics. However, results from the present study indicate that this strain may have a lower tolerance for normal growth conditions associated with an increased relative expression of general stress genes.

\section{Materials and Methods}

\subsection{Fungal Strains, Aflatoxin Biocontrol, and Abiotic Stress Assays}

Freeze-dried samples of strains NRRL 3357 (aflatoxigenic), NRRL 6513 (aflatoxigenic), and NRRL 35739 (non-aflatoxigenic) were received from the NRRL Culture Collection (https://nrrl.ncaur.usda.gov/). Spores of the fungi grown on potato dextrose agar (PDA; Difco) for one week in the dark at $32{ }^{\circ} \mathrm{C}$ were gently harvested and diluted to $10^{4}, 10^{6}$, or $10^{7}$ spores $/ \mathrm{mL}$ in a sterile aqueous solution of $10 \% v / v$ glycerol and $1 \% v / v$ Tween 80 (spore suspension liquid). Spores were stored at $-20^{\circ} \mathrm{C}$ until use. Before each experiment, spores for each strain were inoculated and grown on three plates of PDA at $32{ }^{\circ} \mathrm{C}$ for one week. The new spores were gently harvested in $10 \mathrm{~mL}$ of spore suspension liquid and filtered through eight layers of sterile cheesecloth. Collected spores were stored at $4{ }^{\circ} \mathrm{C}$ for a maximum of two weeks.

To determine if NRRL 35739 was capable of decreasing aflatoxin accumulation, $100 \mu \mathrm{L}$ of $10^{4}$ NRRL 35739 spores/mL was co-inoculated with the same amount of either aflatoxigenic strain NRRL 3357 or NRRL 6513 in three flasks containing $50 \mathrm{~mL}$ of YES medium ( $20 \mathrm{~g}$ of yeast extract, $150 \mathrm{~g}$ of sucrose per liter). Cultures were grown at $32{ }^{\circ} \mathrm{C}$, shaking at $150 \mathrm{rpm}$ on an Innova 2000 platform shaker (New Brunswick Scientific) for six days in the dark. Aflatoxin was extracted from the spent media following a published method with some exceptions [16]. Briefly, $3 \mathrm{~mL}$ from each culture flask was centrifuged at 10,000× $\mathrm{g}$ for $5 \mathrm{~min}$ to pellet hyphae. Two $500 \mu \mathrm{L}$ samples of the supernatant were each quickly mixed with $1 \mathrm{~mL}$ of methyl chloride and centrifuged at $10,000 \times \mathrm{g}$ for $2 \mathrm{~min}$. The organic bottom layers were transferred to a glass vial and allowed to evaporate. Dried extracts were gently dissolved in $100 \mu \mathrm{L}$ methyl chloride; $30 \mu \mathrm{L}$ of the solutions were loaded onto $4 \times 8 \mathrm{~cm}$ TLC silica gel $60 \mathrm{~F} 254$ plates (Millipore Sigma) along with 15 drops of an aflatoxin mix with an unspecified concentration in 
98:2 benzene:acetonitrile (Millipore Sigma). The plates were developed with 8:1 ethyl acetate:toulene. Aflatoxin fluoresced under ultraviolet light. The experiment was replicated three times.

For the abiotic stress assays, $5 \mu \mathrm{L}$ of $10^{6}$ spores of each A. flavus strain were three-point inoculated on three solid YES media (with $15 \mathrm{~g}$ of bacto-agar per liter) and incubated for two days in the dark at $32{ }^{\circ} \mathrm{C}$. After incubation, the diameters of the colonies were measured. Stresses were introduced by amending the sterile medium to contain $5 \mathrm{mM}, 10 \mathrm{mM}$, or $15 \mathrm{mM}$ hydrogen peroxide; $2 \%, 4 \%$, or $8 \%$ $(\mathrm{w} / \mathrm{v})$ sodium chloride; $5 \%, 10 \%$, or $15 \%(v / v)$ glycerol; or by growing cultures at $22^{\circ} \mathrm{C}, 27^{\circ} \mathrm{C}, 37^{\circ} \mathrm{C}$, or $42{ }^{\circ} \mathrm{C}$. The experiment was replicated four times. Two-tailed Student's $t$-tests with the $\alpha$-level set to $10^{-5}$ were performed to find significant differences from the respective control group for each strain.

Growth on a peanut host was also tested. Raw peanuts were purchased from a local supermarket, shelled, and the seed coats were removed. Five kernels were halved, rinsed vigorously with sterile water, and submerged in sterile water or a $10^{7} \mathrm{~A}$. flavus strain spore per milliliter suspension for $30 \mathrm{~min}$. Kernels were shaken to remove excess liquid and placed on a filter paper in a Petri dish with $1 \mathrm{~mL}$ of sterile water. Plates were sealed with Parafilm and incubated for four days in the dark at $32{ }^{\circ} \mathrm{C}$. The experiment was performed three times.

\subsection{RT-PCRs and Comparative Transcriptomics}

Two replicates of the A. flavus strains NRRL 3357, NRRL 6513, and NRRL 35739 were grown on potato dextrose broth for 10 days at $32{ }^{\circ} \mathrm{C}$ in the dark. Total RNA was extracted and converted to cDNA using the Zymo Research Quick-RNA Fungal/Bacterial MiniPrep Kit (Integrated Sciences) and the High-Capacity cDNA Reverse Transcription Kit (Thermo Fisher Scientific) as directed by the manufacturers. The RT-PCR products were stored at $-20^{\circ} \mathrm{C}$. Primers targeting GAPDH and six putative A. flavus NRRL 3357 stress response genes (National Center for Biotechnology Information, NCBI, accessions AFLA_006960, AFLA_019230, AFLA_022380, AFLA_037820, AFLA_060260, AFLA_079830) were used with the DreamTaq Green PCR Master Mix (Table 1). The PCR conditions were denaturation at $95{ }^{\circ} \mathrm{C}$ for $30 \mathrm{~s}$, annealing at $50{ }^{\circ} \mathrm{C}$ for $30 \mathrm{~s}$, and extension at $72{ }^{\circ} \mathrm{C}$ for $1 \mathrm{~min}$, cycling 25 times. Ten microliters of the PCR products were subjected to gel electrophoresis on a $2 \%$ agarose gel. PCRs were repeated once. It was assumed that the three strains expressed GAPDH at similar levels, and the GAPDH PCR products were used as an internal control for the amount of cDNA template used in PCRs.

Table 1. Primers used for PCR and RT-PCR.

\begin{tabular}{|c|c|c|}
\hline Target & Sequences $\left(5^{\prime}-3^{\prime}\right)$ & Amplicon (bp) \\
\hline \multirow{2}{*}{ GAPDH } & F- CACCTACGAGGACATCAAGAAG & \multirow{2}{*}{104} \\
\hline & R- GATCAGGTCAGTGGAGACAATG & \\
\hline \multirow{2}{*}{ AFLA_006960 } & F- CAGACCGACTACCTCAACGA & \multirow{2}{*}{147} \\
\hline & R- GCCTTCCTCTTCCTTGGTCT & \\
\hline \multirow{2}{*}{ AFLA_019230 } & F- AGGGTGGTCTTGGAAAGGTC & \multirow{2}{*}{93} \\
\hline & R- TCTGCTTAACCTTGCCCTCA & \\
\hline \multirow{2}{*}{ AFLA_022380 } & F- CAAGCGCAACACCACAATTC & \multirow{2}{*}{101} \\
\hline & R- CACGTTCACCCTCGTAAACC & \\
\hline \multirow{2}{*}{ AFLA_037820 } & F- CATCAAGCATACCGCCCAAA & \multirow{2}{*}{122} \\
\hline & R- GCTTGGTTAACGCCAGGTAG & \\
\hline \multirow{2}{*}{ AFLA_060260 } & F- GAGGGTGAGAGCAAGGAAGT & \multirow{2}{*}{152} \\
\hline & R- AGGATGCCGTTCTTAAGGCT & \\
\hline \multirow{2}{*}{ AFLA_079830 } & F- CGGTGCTGATCTCCTCATCA & \multirow{2}{*}{71} \\
\hline & R- ACAGAGCGTGAATGATACCAG & \\
\hline
\end{tabular}


Fifty milliliters of potato dextrose broth (Difco) in a $250 \mathrm{~mL}$ Erlenmeyer flask was inoculated with $50 \mu \mathrm{L}$ of $10^{4}$ NRRL 35739 spores $/ \mathrm{mL}$ and incubated for 10 days at $32{ }^{\circ} \mathrm{C}$ in the dark without shaking. Total RNA was extracted from the other culture using a Zymo Research Quick-RNA Fungal/Bacterial kit according to the manufacturer's instructions. The extracted RNA was submitted to GENEWIZ (South Plainfield, New Jersey). After determining that the RNA sample had an RNA Integrity Number of 10.0, the sample was subjected to poly(A) selection and then sequenced on an Illumina HiSeq 2500 platform. Raw reads were uploaded to the NCBI Sequence Read Archive (SRA) database under accession PRJNA520841.

RNA-Seq reads from aflatoxigenic (AF70 and NRRL 3357) and biocontrol (NRRL 18543 and WRRL 1519) strains were retrieved from the NCBI SRA database (Table 2). Read quality was checked with FastQC version 0.11.7 [28]. All the reads were aligned to the genomes of AF70 and NRRL 3357 as these two were the best annotated A. flavus genomes and represented S- and L-morphotypes, which have different gene contents and organizations [29-31]. For this, STAR version 2.6 was used with the accompanying GFF files (NCBI assemblies GCA_000952835.1 and GCA_000006275.2) [31-33]. The output SAM files were converted to sorted BAM files using Samtools version 1.7 [34]. Stringtie version 1.3.5 and Python were used to generate fragments per kilobase of transcript per million mapped reads (FPKM) matrices [35,36]. For each strain, FPKMs were normalized on a scale of 0 to 100 by dividing each number by one-hundredth of the highest FPKM value for that strain. Relative FPKMs were then compared for identification of genes for which (1) the absolute difference in relative FPKM for NRRL 18543 and WRRL 1519 was within 0.5 units, and (2) the fold changes in relative expression in NRRL 35739 were at least 10-fold in difference to that in NRRL 18543 and WRRL 1519. Graphs were generated using Inkscape version 0.91 (available at: https://inkscape.org/en/) and R [37]. Annotations of genes of interest were verified using NCBI BLAST and InterProScan version 5.32 [38,39]. To identify differences in promoter regions, sequences $500 \mathrm{bp}$ upstream of genes of interest were collected and aligned to one another using Clustal Omega [40].

Table 2. General information about RNA-Seq reads from other Aspergillus flavus transcriptomics studies.

\begin{tabular}{llllll}
\hline \multicolumn{1}{c}{ Strain } & $\begin{array}{l}\text { SRA Run } \\
\text { Accession }\end{array}$ & No. Reads & Read Length & Growth Condition ${ }^{\text {a }}$ & Reference \\
\hline AF70 & SRR7962692 & $20,657,024$ & $1 \times 99 \mathrm{bp}$ & $50 \mathrm{~mL} \mathrm{PDB}, 31^{\circ} \mathrm{C}, 10$ days & {$[41]$} \\
NRRL 18543 & SRR7962690 & $22,495,368$ & $1 \times 99 \mathrm{bp}$ & $50 \mathrm{~mL} \mathrm{PDB}, 31^{\circ} \mathrm{C}, 10$ days & {$[41]$} \\
NRRL 3357 & SRR544871 & $13,919,842$ & $2 \times 115 \mathrm{bp}$ & $100 \mathrm{~mL} \mathrm{PDB}, 30^{\circ} \mathrm{C}$, shaking & {$[42]$} \\
& & & $200 \mathrm{rpm}$ & $20 \mathrm{~mL} \mathrm{PDB}, 28^{\circ} \mathrm{C}$, shaking & {$[10]$} \\
WRRL 1519 & SRR5907168 & $36,768,097$ & $1 \times 150 \mathrm{bp}$ & $150 \mathrm{rpm}, 48 \mathrm{~h}$ & \\
\hline
\end{tabular}

a As much information as is available from each respective published study is provided; PDB, potato dextrose broth. All cultures were grown in the dark.

\section{Results}

\subsection{Strain NRRL 35739 was Poor at Biocontrol and Grew More Slowly}

Strains NRRL 3357 and NRRL 6513 produced aflatoxin that was detectable regardless of co-inoculation with NRRL 35739 (Figure 1). For both aflatoxigenic strains, co-inoculation with the non-aflatoxigenic strain did not visibly affect detected toxin accumulation or caused a slight, unquantified decrease in aflatoxin fluorescence. Media in which only NRRL 35739 was inoculated did not have aflatoxin. 


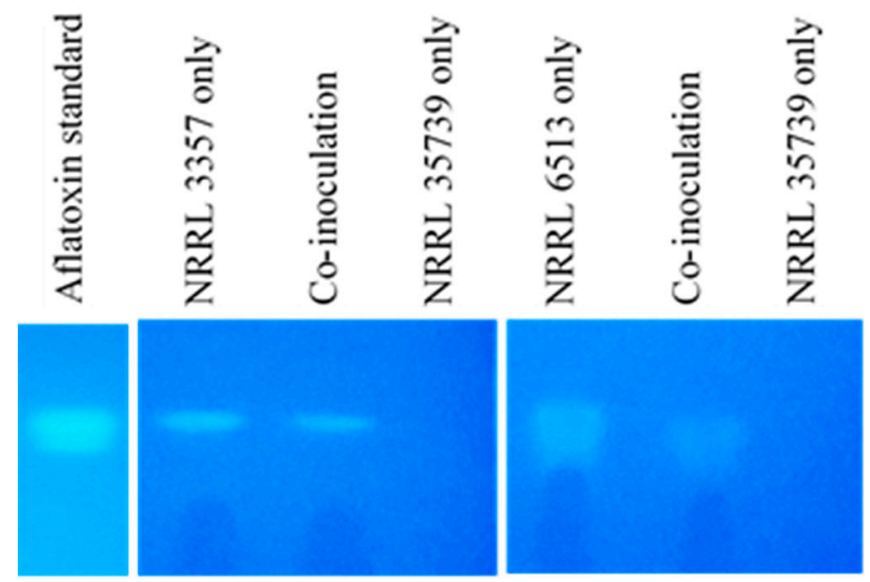

Figure 1. Weak biocontrol ability of A. flavus NRRL 35739. The strain was tested against NRRL 3357 (middle) and NRRL 6513 (right). Co-inoculation of an aflatoxigenic strain with NRRL 35739 did not greatly affect aflatoxin accumulation in the media. The retention factors of the aflatoxin extracts were similar to that of the aflatoxin standard (left). Images are representative of three replicates.

The abilities of the three strains to withstand oxidative, salinity, dehydration, cold, and heat stresses were tested. All of the stressors significantly $\left(p<10^{-5}\right)$ reduced growth except for $2 \%$ sodium chloride (Figure 2). NRRL 35739 generally had smaller colony sizes than NRRL 3357 and NRRL 6513 for most treatment groups. However, the fold changes by which the growths of the strains were affected by each stress were largely consistent. Compared to the other two strains, NRRL 6513 was slightly more tolerant of $15 \mathrm{mM}$ hydrogen peroxide and slightly less tolerant of incubation at $42{ }^{\circ} \mathrm{C}$. NRRL 35739 also formed visibly less thick hyphal coatings on raw peanuts (Figure 3). NRRL 6513, which was generally intermediate in growth between the other two strains on control and amended YES media, sporulated more heavily than the other two strains when grown on peanuts, but not on the solid YES medium. NRRL 35739 sporulated on solid artificial medium.

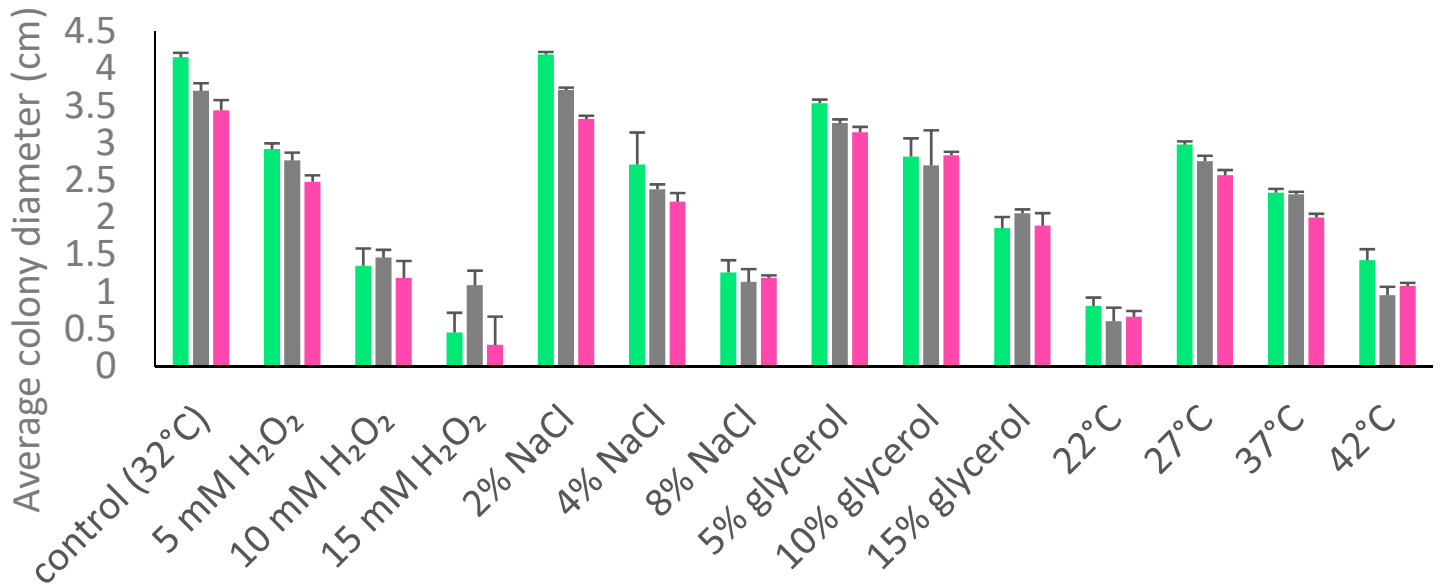

\section{Abiotic stress}

\section{7 - $6513 \square 35739$}

Figure 2. Abiotic stress tolerance of A. flavus NRRL 3357, NRRL 6513, and NRRL 35739. Cultures were grown on solid YES media amended with the indicated stress agents. Colony diameters were measured after two days. Error bars represent one standard deviation above the mean of four replicates. 


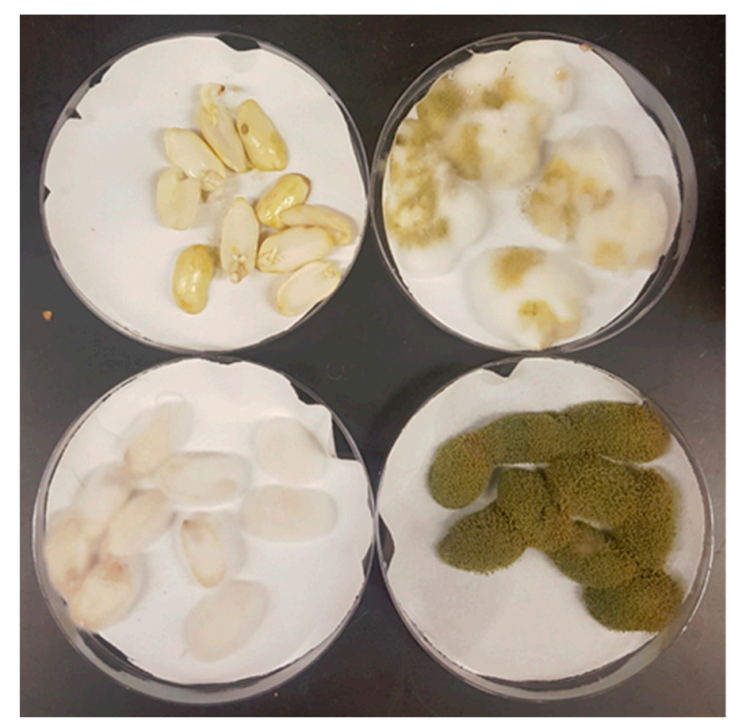

Figure 3. Growth of three A. flavus strains on raw peanuts. After four days, growths of NRRL 35739 on the hosts were less thick than the fluffy or heavily sporulating growths of aflatoxigenic strains NRRL 3357 and NRRL 6513. Clockwise from the top left: negative control, NRRL 3357, NRRL 6513, and NRRL 35739. The image is representative of three replicates.

\subsection{RNA-Seq Data Revealed Differences in the Transcriptomes of A. flavus Strains}

A yield of 283,801,877 high-quality $(88.24 \% \geq$ Q30 with a mean quality score of 37.2$) 2 \times 150 \mathrm{bp}$ paired-end sequencing reads without adapter sequences of the NRRL 35739 transcriptome was obtained. The majority of RNA-Seq reads from strains AF70, NRRL 18543, NRRL 3357, NRRL 35739, and WRRL 1519 were aligned to the genomes of AF70 and NRRL 3357 (Table 3). Generally, the reads better aligned to the genome of AF70 than to that of NRRL 3357 for unknown reasons. However, most of the expressed genes were commonly expressed by all of the strains, regardless of which genome was used for read alignment (Figure 4).

Table 3. Mapping of $A$. flavus RNA-Seq reads.

\begin{tabular}{lllll}
\hline \multicolumn{1}{c}{ Strain } & $\begin{array}{l}\text { Reads Aligned to } \\
\text { AF70 Genome (\%) }\end{array}$ & $\begin{array}{l}\text { No. Genes } \\
\text { Expressed }\end{array}$ & $\begin{array}{l}\text { Reads Aligned to } \\
\text { NRRL 3357 } \\
\text { Genome (\%) }\end{array}$ & $\begin{array}{l}\text { No. Genes } \\
\text { Expressed }\end{array}$ \\
\hline AF70 & 98.04 & 11,932 & 76.81 & 11,730 \\
NRRL 18543 & 97.86 & 11,324 & 54.55 & 11,511 \\
NRRL 3357 & 65.98 & 11,708 & 65.79 & 12,180 \\
NRRL 35739 & 84.24 & 12,512 & 78.54 & 12,911 \\
WRRL 1519 & 95.32 & 11,941 & 89.84 & 12,291 \\
\hline
\end{tabular}

a Expressed genes were those with fragments per kilobase of transcript per million mapped reads (FPKMs) greater than 0.

Following read alignment to either genome, genes with FPKMs greater than 0 were considered to be expressed by a particular strain. Genes that were uniquely expressed by the non-aflatoxigenic strains NRRL 18543, WRRL 1519, or NRRL 35739 were annotated mostly as hypothetical proteins and had low relative expressions (relative FPKM $<0.2$ ). Three of the few functionally annotated genes expressed only by NRRL 18543 or WRRL 1519 were membrane transporters, oxidoreductases, and polyketide synthetases. None of the genes exclusively expressed by both had functional annotations. Among the genes that were uniquely expressed by NRRL 35739, the genes were mostly hypothetical, transporters/permeases, or dehydrogenases. The genes expressed only by AF70 and NRRL 3357 included genes in the aflatoxin biosynthesis gene cluster, as well as a glucose dehydrogenase and a multidrug resistance protein. 


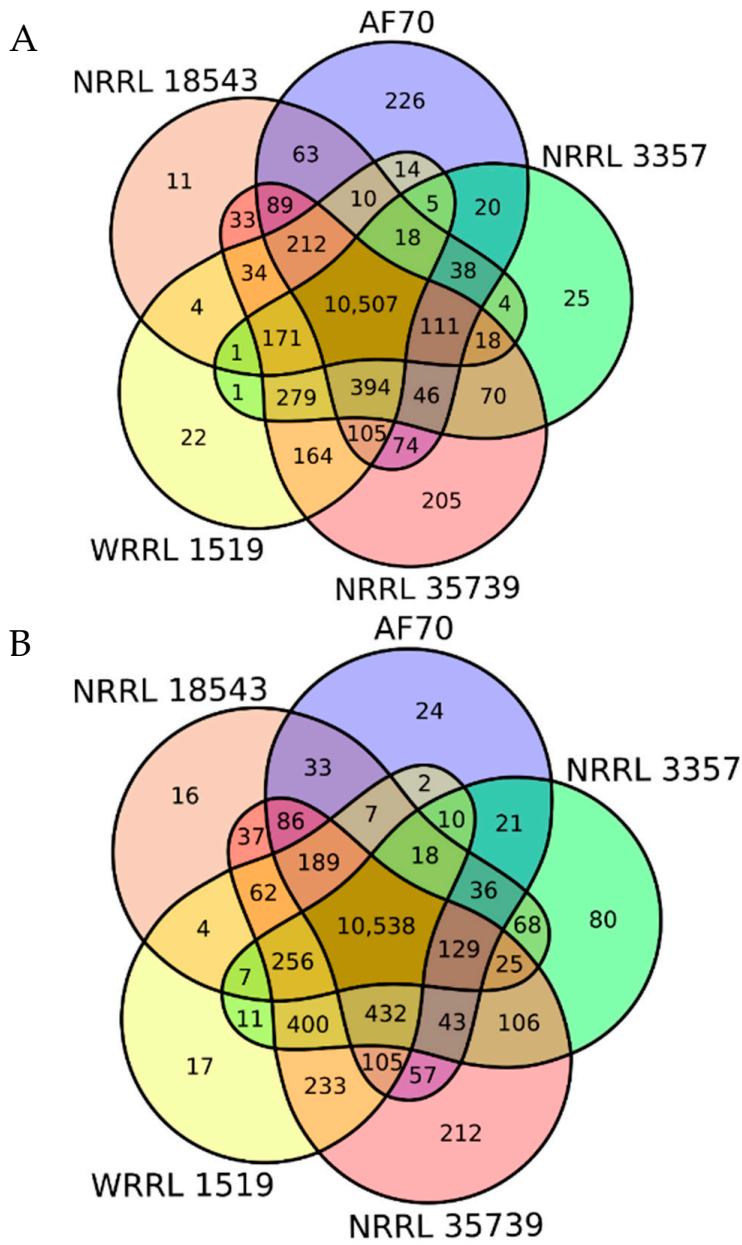

Figure 4. Venn diagrams of commonly expressed genes for selected A. flavus strains. Genes that had FPKMs greater than 0 were counted according to RNA sequence read alignment to the genomes of (A) AF70 or (B) NRRL 3357. A total of 222 AF70 genes and 221 NRRL 3357 genes were not expressed by any of the five strains and are not represented in the figure. The total number of annotated genes in the AF70 and NRRL 3357 genomes were 13,196 and 13,485, respectively.

As expected, the aflatoxigenic strains expressed most of the aflatoxin biosynthesis genes, regardless of to which genome the RNA reads were aligned, although AF70 did not detectably express aflLa, afli, or aflQ, and NRRL 3357 did not express aflV. In alignment AF70 (RNA reads aligned to the genome of AF70), NRRL 3357 additionally did not express aflLa. The non-aflatoxigenic strains also expressed some of the genes that were present in their respective genomes. For both alignments, strain NRRL 18543 expressed aflT to aflS, aflMa, and aflNa and aflX to aflYe. WRRL 1519 expressed aflN to aflL, aflQ, and aflW and aflYb to aflYe. NRRL 35739 expressed aflM to aflG, aflP to aflW, and aflYa to aflYe; it was the only one of the non-aflatoxigenic strains to express aflM, aflP, aflK, and aflV. According to alignment AF70, NRRL 18543 expressed aflF and aflU, and NRRL 35739 expressed aflI, aflO, aflX, and aflY. NRRL 35739 expressed all aflatoxin biosynthesis genes that NRRL 18543 and WRRL 1519 did.

For both alignments, the most highly expressed annotated genes for AF70 and NRRL 18543 were similar: a glutamine synthetase, three conidiation genes, an extracellular 3-ketosteroid 1-dehydrogenase, and a heat shock protein. NRRL 3357 highly expressed two allergens, a pyruvate decarboxylase, a translation elongation factor, an $\mathrm{ADP} / \mathrm{ATP}$ carrier protein, and a manganese superoxide dismutase. For WRRL 1519, the most highly expressed genes included a glyceraldehyde 3-phosphate dehydrogenase, a $60 \mathrm{~S}$ ribosomal protein, and the same manganese superoxide dismutase and ADP/ATP carrier protein as NRRL 3357. The top genes expressed by NRRL 35739 included a heat shock protein, one of the two 
allergens highly expressed by NRRL 3357, a CsbD-like general stress response protein, a translation elongation factor, and a high expression lethality protein.

\subsection{NRRL 35739 had Higher Relative Expression of Six Stress-Related Genes}

Relative gene expressions were used to identify genes that had large differences between the strong biocontrol strains and NRRL 35739. A total of 26 genes from the AF70 and NRRL 3357 alignments had relative gene expressions that were similar between strains NRRL 18543 and WRRL 1519, but different for NRRL 35739 (Tables 4 and 5). Coincidentally, all the identified genes had higher relative expression in NRRL 35739. Seven of the genes (AFLA70_502g000700, AFLA70_560g000680, AFLA70_73g004291, AFLA70_89g003151, AFLA_019230, AFLA_037820, and AFLA_060260) were involved in stress response.

The most highly expressed functionally annotated genes of interest in either alignment were the heat shock protein homologs AFLA70_560g000680 and AFLA_060260. The only other gene with higher relative expression in the NRRL 3357 alignment of NRRL 35739 reads was the hypothetical gene AFLA_099070. The relative transcriptome landscapes of the strains were visualized (Figure S1).

Table 4. Genes with differential relative expression of interest in the A. flavus AF70 alignment.

\begin{tabular}{llcc}
\hline \multicolumn{1}{c}{ Gene Name } & \multicolumn{1}{c}{ Putative Description } & $\begin{array}{c}\text { NRRL 35739 } \\
\text { Relative FPKM }\end{array}$ & $\begin{array}{c}\text { Average Fold } \\
\text { Difference }\end{array}$ \\
\hline AFLA70_147g002360 & alternative oxidase & 27 & 202 \\
AFLA70_21g004231 & isocitrate lyase AcuD & 35 & 64 \\
AFLA70_263g001160 & phosphoenolpyruvate carboxykinase AcuF & 14 & 38 \\
AFLA70_286g001550 & chitin synthesis regulation RCR superfamily & 16 & 40 \\
AFLA70_30g004530 & membrane associated proteins in eicosanoid and & 11 & 17 \\
AFLA70_338g001370 & 4-carboxymutabonolism family protein & 33 & 407 \\
AFLA70_502g000700 & heat shock protein, Hsp20-like & 12 & 619 \\
AFLA70_52g003980 & domain of unknown function superfamily DUF1857 & 15 & 39 \\
AFLA70_535g000630 & molecular chaperone Hsp70 & 15 & 10 \\
AFLA70_560g000680 & heat shock protein, Hsp20-like & 100 & 280 \\
AFLA70_570g000531 & domain of unknown function superfamily DUF4436; & 14 & 59 \\
AFLA70_6g007820 & metal-dependent hydrolase & 14 & 36 \\
AFLA70_73g004291 & mitochondical protein AFLA70_6g007820 & 16 & 16 \\
AFLA70_89g003151 & CsbD-like general stress response protein & 40 & 274 \\
\hline
\end{tabular}

Table 5. Genes with differential relative expression of interest in the A. flavus NRRL 3357 alignment.

\begin{tabular}{llcc}
\hline Gene Name & \multicolumn{1}{c}{ Putative Description } & $\begin{array}{c}\text { NRRL 35739 } \\
\text { Relative FPKM }\end{array}$ & $\begin{array}{c}\text { Average Fold } \\
\text { Difference }\end{array}$ \\
\hline AFLA_006100 & domain of unknown function superfamily DUF4243 & 7 & 20 \\
AFLA_019230 & CsbD-like general stress response protein & 28 & 143 \\
AFLA_035070 & alternative oxidase & 16 & 113 \\
AFLA_036370 & phosphoenolpyruvate carboxykinase AcuF & 9 & 17 \\
AFLA_037820 & heat shock protein Hsp20 or Hsp30-like & 7 & 300 \\
AFLA_050290 & amidohydrolase family protein & 6 & 36 \\
AFLA_052400 & isocitrate lyase AcuD & 20 & 30 \\
AFLA_057980 & conserved hypothetical protein & 12 & 16 \\
AFLA_060260 & heat shock protein Hsp20 or Hsp30 & 58 & 130 \\
AFLA_097370 & chitin synthesis regulation RCR superfamily & 9 & 17 \\
AFLA_097530 & domain of unknown function superfamily DUF1857 & 9 & 19 \\
AFLA_124980 & 4-carboxymuconolactone decarboxylase & 24 & 166 \\
\hline
\end{tabular}

The higher relative expression of two heat shock proteins in both alignments prompted a closer look at the relative expressions of other genes annotated as being involved in heat shock and stress responses (Table 6 and Figure 5). One pair of homologous AF70 and NRRL 3357 heat shock proteins (AFLA70_71g003911 and AFLA_052860) were relatively more expressed in AF70 and NRRL 18543. Higher relative expressions were observed for six other pairs of homologous genes (AFLA70_166g001980, AFLA70_502g000700, AFLA70_535g000630, AFLA70_560g000680, AFLA70_793g000140, AFLA70_89g003151, AFLA_006960, AFLA_019230, AFLA_022380, AFLA_037820, 
AFLA_060260, and AFLA_079830), NRRL 35739. However, these data were not confirmed by RT-PCR (Figure 6). Comparisons of the upstream regions of the genes of interest did not reveal any differences among them.

Table 6. Putative descriptions of stress-related A. flavus AF70 and NRRL 3357 genes.

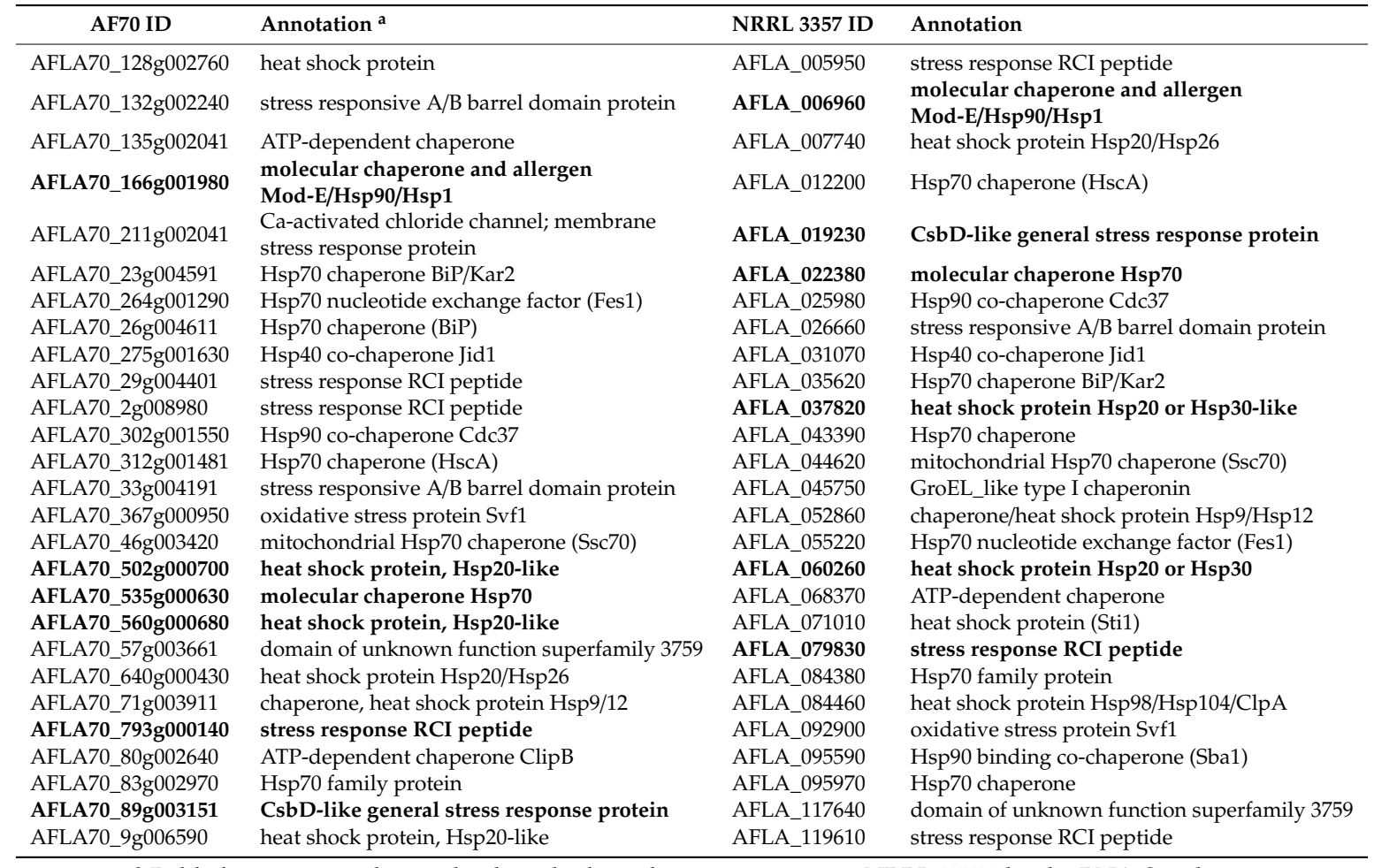

${ }^{a}$ Bolded genes were observed to have higher relative expression in NRRL 35739 by the RNA-Seq data.

A

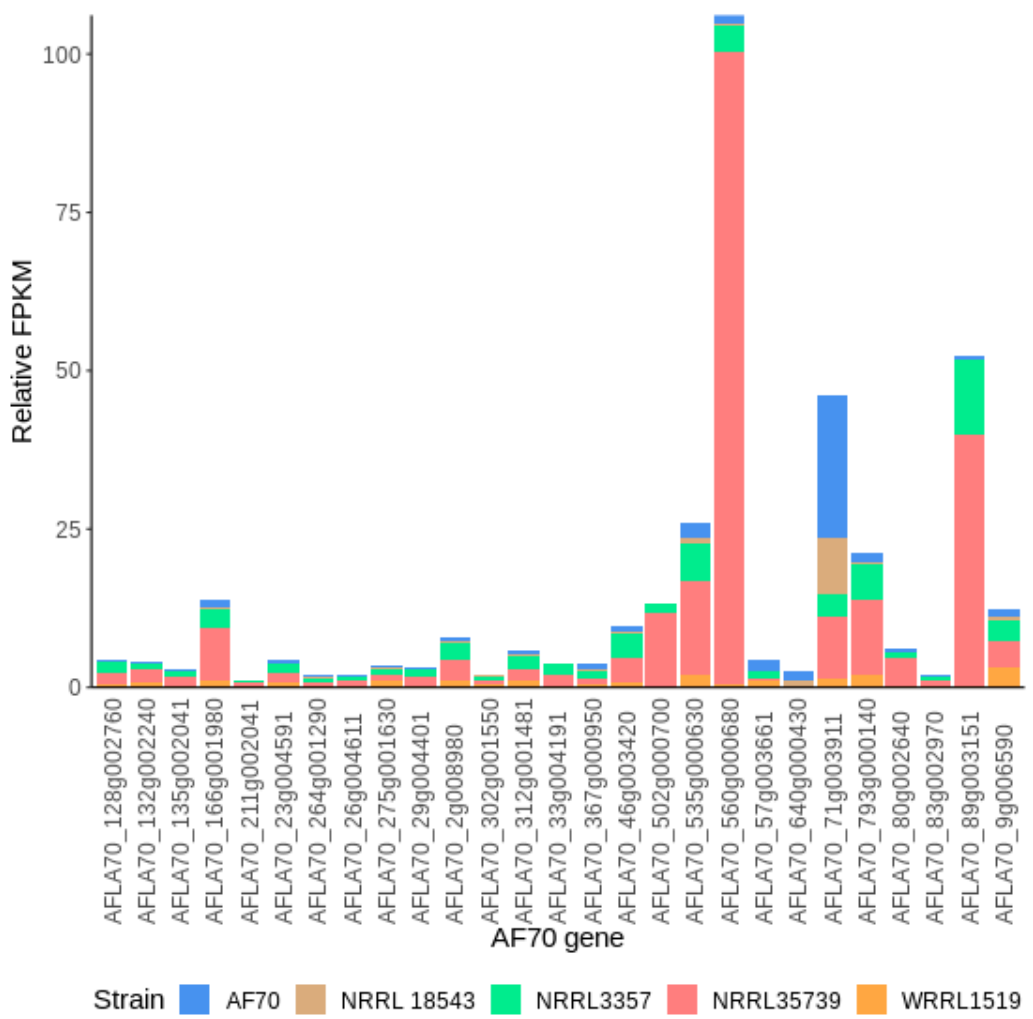

Figure 5. Cont. 


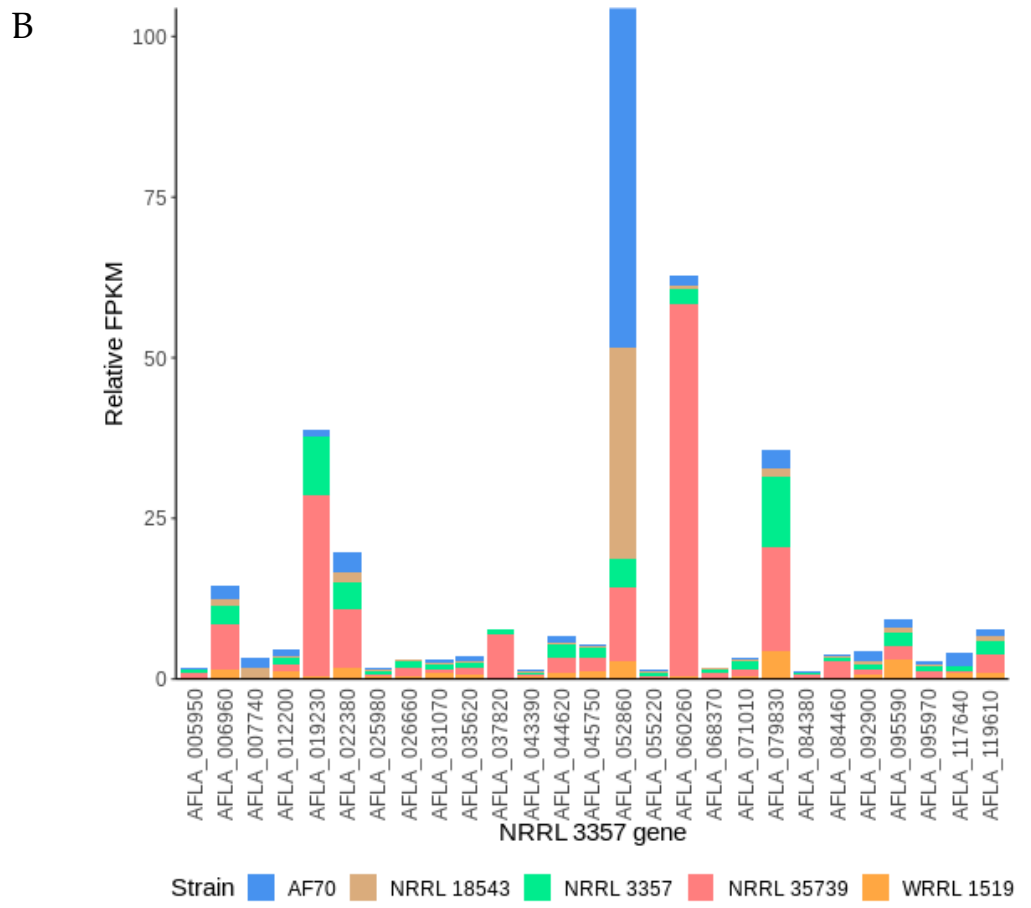

Figure 5. Relative expressions of heat shock and other stress-related genes in five A. flavus strains. Graphs were based on (A) AF70 and (B) NRRL 3357 alignments. Genes with total relative FPKMs less than 1 were excluded. Gene functional annotations are described in Table 6.
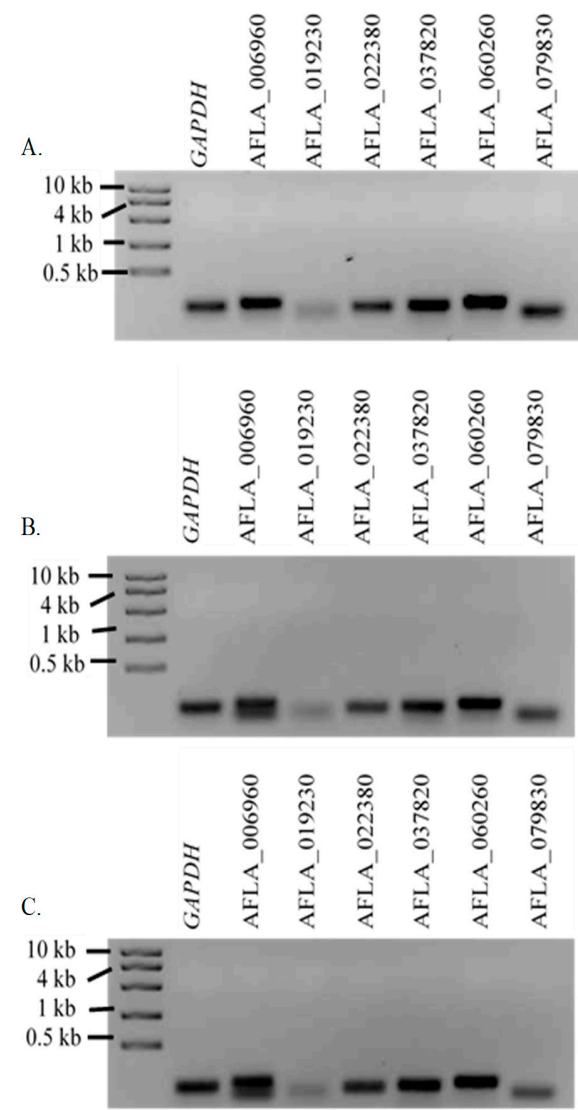

Figure 6. Transcript accumulation of selected genes by RT-PCR. GAPDH served as a control for template loading. Intensities of bands were visually compared among A. flavus strains (A) NRRL 3357, (B) NRRL 6513, and (C) NRRL 35739. 


\section{Discussion}

It was hypothesized that the poor biocontrol strain A. flavus NRRL 35739 would have a lower tolerance for oxidative stress than aflatoxigenic strains as well as reduced expression of redox genes compared to the stronger biocontrol agents. However, NRRL 35739 generally grew slower regardless of the tested abiotic stresses. From preliminary comparative transcriptomics with data derived from other studies, it seemed that the redox genes mostly were expressed at similar relative levels as aflatoxigenic and strong biocontrol strains. Instead, genes for heat shock proteins (AFLA70_166g001980, AFLA70_502g000700, AFLA70_535g000630, AFLA70_560g000680, AFLA_006960, AFLA_022380, AFLA_037820, and AFLA_060260), a CsbD-like protein (AFLA70_89g003151/AFLA_019230), and a rare cold inducible (RCI) stress response peptide (AFLA70_793g000140/AFLA_079830) appeared to be relatively more highly expressed in NRRL 35739 compared to the other four A. flavus strains. RT-PCRs did not confirm higher expressions of the genes of interest in NRRL 35739 than in NRRL 3357. It would be more informative to test the relative expressions of these genes between NRRL 35739 and a strong biocontrol strain, which, unfortunately, we were unable to obtain for this work.

Heat shock proteins are a ubiquitous family of proteins involved in responses to many abiotic stresses, including heat, salinity, and oxidative stresses [43-47]. They are named by their molecular weight in kildodaltons and often serve as molecular chaperones, helping nascent and denatured peptides fold properly or be tagged for degradation. Aspergillus heat shock protein 90, an antigen in allergic bronchopulmonary aspergillosis by Aspergillus fumigatus, promotes drug resistance and conidiation and is involved in signal transduction [48-56]. Hsp70 facilitates protein folding and plays a role in resistance to antifungal drugs [57,58]. Hsp42 suppresses aggregation of cytosolic proteins [59]. Hsp40 is a co-factor for Hsp70 and facilitates protein folding [44,60]. Hsp30 interacts with Hsp80 and Hsp70 to help fold polypeptides and helps conserve energy by inhibiting ATPase [61-63]. Heat shock proteins in the 20-30 kD range facilitate protection against heat and oxidative stresses, nuclear import of a protein kinase in human cardiac cells, and cellular motility [64-67]. Hsp12 is upregulated during heat, oxidative, and cold stresses, increasing membrane stability and causing morphological changes $[61,68,69]$. Homologous to Hsp12, Hsp9 is involved in passing the G2-M checkpoint of the cell cycle and is induced by heat shock, glucose deprivation, and stationary growth in the yeast Schizosaccharomyces pombe [70,71].

$\operatorname{csbD}$ is a gene of unknown function that is induced during stress in bacteria [72-75]. AFLA70_89g003151 and AFLA_019230 were originally described as mismatched base pair and cruciform DNA recognition proteins. However, both contain the conserved CsbD superfamily domain in the middle of the predicted protein and no other known domains. The RCI stress peptide responds to several abiotic stresses in plants and Saccharomyces cerevisiae and localizes to yeast membranes [76-78]. All genes of interest are upregulated by hydrogen peroxide and resveratrol in NRRL 3357, except for AFLA_019230 [17,79]. AFLA_060260 is additionally significantly upregulated in A. flavus NRRL 3357 at $37^{\circ} \mathrm{C}$ compared to $28^{\circ} \mathrm{C}$ in YES medium [80]. The Aspergillus nidulans heat shock protein genes AN2530 (Hsp20-like), AN3463 (Hsp40-like), AN4037 (hypothetical thermotolerance gene), and AN7892 (Hsp20/Hsp30-like) have increased expression under carbon starvation, while expression of an RCI peptide gene, AN2312, decreases [81]. Heat shock proteins are important for response to nutrient stress in S. cerevisiae and Escherichia coli [82-86].

It was not clear why NRRL 35739 may have had increased relative expression of stress proteins. If NRRL 35739 was reacting to heat stress, there would have been accompanying high expressions of oxidative stress responses [87-89]. The strain was grown at $32^{\circ} \mathrm{C}$ before RNA extraction unlike the other strains, which were grown at $28-31^{\circ} \mathrm{C}$. However, the differences in temperature were minor and within a non-detrimental temperature range for $A$. flavus growth [90-92]. High relative expressions of an Hsp9/12 gene, AFLA70_71g003911/AFLA_052860, for strains AF70 and NRRL 18543 were also noted and likewise remain unexplained. The transcriptomic data for the strains were collected during the same experiment, so the results may have been particular to A. flavus strains with S-morphotype lineages or to certain experimental conditions that were not replicated in the present study. 
Increased expression of stress proteins might indicate nutrient stress. Organisms in the same area compete for resources they need to grow, survive, and reproduce. The ability to be a better competitor relies on the ability to better utilize available resources and/or be better able to tolerate less than optimal conditions [93]. A. flavus biocontrol strains differ from most other fungal biocontrol agents in that A. flavus strains are used to reduce growth and toxin production by other strains of the same species. Generally, intraspecific competition has stronger negative effects than interspecific competition because members of the same species are more likely to occupy the same ecological niche [94]. In laboratory media, the most important factors likely at play are declining nutrient availabilities and increasing build-up of waste compounds. The generally slower growth and reduced spore production of $A$. flavus NRRL 35739 on artificial media and peanut hosts fits into the hypothesis that poor biocontrol strains are less able to out-grow toxigenic strains [18,19].

While the transcriptomics data suggest reasons why strain NRRL 35739 is a poor biocontrol agent, there nevertheless were several drawbacks to the chosen experimental and analytical methods. The cell culture conditions were not uniform across the various published studies, and the magnitudes of RNA reads and transcript counts also were very different. Conversion of the FPKMs into relative FPKMs permitted fairer comparison. However, this and the high thresholds for identification of genes only with large differences in relative expression among strains likely resulted in type II errors. None of the studies had biological or experimental replicates, and without replicates, statistical testing could not be performed. RT-PCR results did not show the expected large differences in transcript accumulation of the six stress response genes in strains NRRL 3357, NRRL 6513, and NRRL 35739, which may indicate fault(s) with the bioinformatics analysis or the RT-PCR experiment. Alternatively, the relative differences did not necessarily translate into large differences in absolute RNA transcript accumulation, at least for NRRL 35739 compared to the tested aflatoxigenic strains. It is still unknown if the differences would be more apparent between NRRL 35739 and a strong biocontrol agent. Additionally, RT-PCR primers for AFLA_006960 appeared to yield a second smaller product for strains NRRL 6513 and NRRL 35739. It is possible that mRNAs in these strains were subjected to alternative splicing not present in NRRL 3357.

Nonetheless, this pilot study provides an opening into the study of how genetic factors and abiotic stress tolerance may influence competitive growth by non-aflatoxigenic strains of $A$. flavus. To the authors' knowledge, there are no previously published studies on the genetics of weak aflatoxin biocontrol agents; most relevant studies focus on identifying strong biocontrol agents. It is of particular interest that NRRL 35739 is the only non-aflatoxigenic strain for which researchers note that the strain sometimes increases aflatoxin accumulation [26]. The findings reported here provide other scientists with a starting point to further investigate how tolerance to abiotic stresses may influence competitive growth by non-aflatoxigenic strains of $A$. flavus. NRRL 35739 serves as a useful control for research into the largely uninvestigated factors that influence aflatoxin production when different $A$. flavus strains are grown together and the general mechanisms by which biocontrol strategies mitigate mycotoxin production in agriculture.

Supplementary Materials: The following are available online at http://www.mdpi.com/2309-608X/5/2/53/s1. Figure S1. Relative gene expression based on read alignment to NRRL 3357. FPKM values were normalized to a 0 to 100 scale. Images were grouped by chromosomal arm.

Author Contributions: Conceptualization, methodology, data analysis and curation, and manuscript draft preparation, K.K.P; manuscript review and editing, K.K.P., G.Y., J.W.B., and S.-S.T.H.; funding acquisition, J.W.B. and S.-S.T.H.

Funding: This work was funded by the USDA-ARS Non-Assistance Cooperative Agreement (no. 58-2030-6-053). Use of a company or product name by the United States Department of Agriculture does not imply approval or recommendation of the product to the exclusion of others that may be suitable.

Acknowledgments: Aspergillus flavus strains NRRL 3357, NRRL 6513, and NRRL 35739 were obtained from the ARS Culture Collection.

Conflicts of Interest: The authors declare no conflicts of interest. 


\section{References}

1. Liu, Y.; Wu, F. Global burden of aflatoxin-induced hepatocellular carcinoma: A risk assessment. Environ. Health Perspect. 2010, 118, 818-824. [CrossRef]

2. Mitchell, N.J.; Bowers, E.; Hurburgh, C.; Wu, F. Potential economic losses to the US corn industry from aflatoxin contamination. Food Addit. Contam. Part A 2016, 33, 540-550. [CrossRef]

3. Kumar, P.; Mahato, D.K.; Kamle, M.; Mohanta, T.K.; Kang, S.G. Aflatoxins: A global concern for food safety, human health and their management. Front. Microbiol. 2016, 7, 2170. [CrossRef]

4. Alshannaq, A.; Yu, J.-H. Occurrence, toxicity, and analysis of major mycotoxins in food. Int. J. Environ. Res. Public Health 2017, 14, 632. [CrossRef]

5. Abbas, H.K.; Accinelli, C.; Shier, W.T. Biological control of aflatoxin contamination in U.S. crops and the use of bioplastic formulations of Aspergillus flavus biocontrol strains to optimize application strategies. J. Agric. Food Chem. 2017, 65, 7081-7087. [CrossRef]

6. Ojiambo, P.S.; Battilani, P.; Cary, J.W.; Blum, B.H.; Carbone, I. Cultural and genetic approaches to manage aflatoxin contamination: Recent insights provide opportunities for improved control. Phytopathology 2018, 108, 1024-1037. [CrossRef]

7. Chang, P.-K.; Horn, B.W.; Dorner, J.W. Sequence breakpoints in the aflatoxin biosynthesis gene cluster and flanking regions in nonaflatoxigenic Aspergillus flavus isolates. Fungal Genet. Biol. 2005, 42, 914-923. [CrossRef]

8. Adhikari, B.N.; Bandyopadhyay, R.; Cotty, P.J. Degeneration of aflatoxin gene clusters in Aspergillus flavus from Africa and North America. AMB Express 2016, 6, 62. [CrossRef]

9. Moore, G.G.; Singh, R.; Horn, B.W.; Carbone, I. Recombination and lineage-specific gene loss in the aflatoxin gene cluster of Aspergillus flavus. Mol. Ecol. 2009, 18, 4870-4887. [CrossRef]

10. Yin, G.; Hua, S.; Pennerman, K.K.; Yu, J.; Bu, L.; Sayre, R.T.; Bennett, J.W. Genome sequence and comparative analyses of atoxigenic Aspergillus flavus WRRL 1519. Mycologia 2018, 110, 482-493. [CrossRef]

11. Chang, P.-K.; Abbas, H.K.; Weaver, M.A.; Ehrlich, K.C.; Scharfenstein, L.L.; Cotty, P.J. Identification of genetic defects in the atoxigenic biocontrol strain Aspergillus flavus K49 reveals the presence of a competitive recombinant group in field populations. Int. J. Food Microbiol. 2012, 154, 192-196. [CrossRef]

12. Alshannaq, A.F.; Gibbons, J.G.; Lee, M.K.; Han, K.H.; Hong, S.B.; Yu, J.H. Controlling aflatoxin contamination and propagation of Aspergillus flavus by a soy-fermenting Aspergillus oryzae strain. Sci. Rep. 2018, 8, 16871. [CrossRef]

13. Dorner, J.W. Efficacy of a biopesticide for control of aflatoxins in corn. J. Food Prot. 2010, 73, 495-499. [CrossRef]

14. Cotty, P.J.; Bhatnagar, D. Variability among atoxigenic Aspergillus flavus strains in ability to prevent aflatoxin contamination and production of aflatoxin biosynthetic pathway enzymes. Appl. Environ. Microbiol. 1994, 60, 2248-2251.

15. Hruska, Z.; Rajasekaran, K.; Yao, H.; Kincaid, R.; Darlington, D.; Brown, R.L.; Bhatnagar, D.; Cleveland, T.E. Co-inoculation of aflatoxigenic and non-aflatoxigenic strains of Aspergillus flavus to study fungal invasion, colonization, and competition in maize kernels. Front. Microbiol. 2014, 5, 122. [CrossRef]

16. Fountain, J.C.; Scully, B.T.; Chen, Z.Y.; Gold, S.E.; Glenn, A.E.; Abbas, H.K.; Lee, R.D.; Kemerait, R.C.; Guo, B. Effects of hydrogen peroxide on different toxigenic and atoxigenic isolates of Aspergillus flavus. Toxins (Basel) 2015, 7, 2985-2999. [CrossRef]

17. Fountain, J.C.; Bajaj, P.; Pandey, M.; Nayak, S.N.; Yang, L.; Kumar, V.; Jayale, A.S.; Chitikineni, A.; Zhuang, W.; Scully, B.T.; et al. Oxidative stress and carbon metabolism influence Aspergillus flavus transcriptome composition and secondary metabolite production. Sci. Rep. 2016, 6, 38747. [CrossRef]

18. Wicklow, D.T.; Bobell, J.R.; Palmquist, D.E. Effect of intraspecific competition by Aspergillus flavus on aflatoxin formation in suspended disc culture. Mycol. Res. 2003, 107, 617-623. [CrossRef]

19. Huang, C.; Jha, A.; Sweany, R.; DeRobertis, C.; Damann, K.E., Jr. Intraspecific aflatoxin inhibition in Aspergillus flavus is thigmoregulated, independent of vegetative compatibility group and is strain dependent. PLoS ONE 2011, 6, e23470. [CrossRef]

20. Morales, H.; Sanchis, V.; Coromines, J.; Ramos, A.J.; Marín, S. Inoculum size and intraspecific interactions affects Penicillium expansum growth and patulin accumulation in apples. Food Microbiol. 2008, 25, 378-385. [CrossRef] 
21. Roze, L.V.; Laivenieks, M.; Hong, S.Y.; Wee, J.; Wong, S.S.; Vanos, B.; Awad, D.; Ehrlich, K.C.; Linz, J.E. Aflatoxin biosynthesis is a novel source of reactive oxygen species-A potential redox signal to initiate resistance to oxidative stress? Toxins (Basel) 2015, 7, 1411-1430. [CrossRef] [PubMed]

22. Grintzalis, K.; Vernardis, S.I.; Klapa, M.I.; Georgiou, C.D. Role of oxidative stress in sclerotial differentiation and aflatoxin $\mathrm{B}_{1}$ biosynthesis in Aspergillus flavus. Appl. Environ. Microbiol. 2014, 80, 5561-5571. [CrossRef] [PubMed]

23. Probst, C.; Bandyopadhyay, R.; Cotty, P.J. Diversity of aflatoxin-producing fungi and their impact on food safety in sub-Saharan Africa. Int. J. Food Microbiol. 2014, 174, 113-122. [CrossRef] [PubMed]

24. Mehl, H.L.; Cotty, P.J. Variation in competitive ability among isolates of Aspergillus flavus from different vegetative compatibility groups during maize infection. Phytopathology 2010, 100, 150-159. [CrossRef] [PubMed]

25. Alaniz Zanon, M.S.; Clemente, M.P.; Chulze, S.N. Characterization and competitive ability of non-aflatoxigenic Aspergillus flavus isolated from the maize agro-ecosystem in Argentina as potential aflatoxin biocontrol agents. Int. J. Food Microbiol. 2018, 277, 58-63. [CrossRef] [PubMed]

26. Horn, B.; Dorner, J. Evaluation of different genotypes of nontoxigenic Aspergillus flavus for their ability to reduce aflatoxin contamination in peanuts. Biocontrol Sci. Technol. 2011, 21, 865-876. [CrossRef]

27. Eshelli, M.; Qader, M.M.; Jambi, E.J.; Hursthouse, A.S.; Rateb, M.E. Current status and future opportunities of omics tools in mycotoxin research. Toxins (Basel) 2018, 10, 433. [CrossRef] [PubMed]

28. Andrews, S. FastQC: A Quality Control Tool for High Throughput Sequence Data. Available online: http://www.bioinformatics.babraham.ac.uk/projects/fastqc/ (accessed on 1 October 2018).

29. Chang, P.-K.; Ehrlich, K.C.; Hua, S.S. Cladal relatedness among Aspergillus oryzae isolates and Aspergillus flavus S and L morphotype isolates. Int. J. Food Microbiol. 2006, 108, 172-177. [CrossRef]

30. Ohkura, M.; Cotty, P.J.; Orbach, M.J. Comparative genomics of Aspergillus flavus S and L morphotypes yield insights into niche adaptation. G3 (Bethesda) 2018, 8, 3915-3930. [CrossRef]

31. Gilbert, M.K.; Mack, B.M.; Moore, G.G.; Downey, D.L.; Lebar, M.D.; Joardar, V.; Losada, L.; Yu, J.; Nierman, W.C.; Bhatnagar, D. Whole genome comparison of Aspergillus flavus L-morphotype strain NRRL 3357 (type) and S-morphotype strain AF70. PLoS ONE 2018, 13, e0199169. [CrossRef]

32. Dobin, A.; Davis, C.A.; Schlesinger, F.; Drenkow, J.; Zaleski, C.; Jha, S.; Batut, P.; Chaisson, M.; Gingeras, T.R. STAR: Ultrafast universal RNA-seq aligner. Bioinformatics 2013, 29, 15-21. [CrossRef] [PubMed]

33. Nierman, W.C.; Yu, J.; Fedorova-Abrams, N.D.; Losada, L.; Cleveland, T.E.; Bhatnagar, D.; Bennett, J.W.; Dean, R.; Payne, G.A. Genome sequence of Aspergillus flavus NRRL 3357, a strain that causes aflatoxin contamination of food and feed. Genome Announc. 2015, 3, e00168-15. [CrossRef] [PubMed]

34. Li, H.; Handsaker, B.; Wysoker, A.; Fennell, T.; Ruan, J.; Homer, N.; Marth, G.; Abecasis, G.; Durbin, R. The sequence alignment/map format and SAMtools. Bioinformatics 2009, 25, 2078-2079. [CrossRef] [PubMed]

35. Love, M.I.; Huber, W.; Anders, S. Moderated estimation of fold change and dispersion for RNA-seq data with DESeq2. Genome Biol. 2014, 15, 550. [CrossRef] [PubMed]

36. Pertea, M.; Pertea, G.M.; Antonescu, C.M.; Chang, T.C.; Mendell, J.T.; Salzberg, S.L. StringTie enables improved reconstruction of a transcriptome from RNA-seq reads. Nat. Biotechnol. 2015, 33, 290-295. [CrossRef] [PubMed]

37. Dusa, A. Package 'venn'. Available online: https://cran.r-project.org/web/packages/venn/venn.pdf (accessed on 1 October 2018).

38. Jones, P.; Binns, D.; Chang, H.Y.; Fraser, M.; Li, W.; McAnulla, C.; McWilliam, H.; Maslen, J.; Mitchell, A.; Nuka, G.; et al. InterProScan 5: Genome-scale protein function classification. Bioinformatics 2014, 30, 1236-1240. [CrossRef] [PubMed]

39. Altschul, S.F.; Gish, W.; Miller, W.; Myers, E.W.; Lipman, D.J. Basic local alignment search tool. J. Mol. Biol. 1990, 215, 403-410. [CrossRef]

40. Sievers, F.; Wilm, A.; Dineen, D.; Gibson, T.J.; Karplus, K.; Li, W.; Lopez, R.; McWilliam, H.; Remmert, M.; Söding, J. Fast, scalable generation of high-quality protein multiple sequence alignments using Clustal Omega. Mol. Syst. Biol. 2011, 7, 539. [CrossRef]

41. Espindola, A.S.; Schneider, W.; Cardwell, K.F.; Carrillo, Y.; Hoyt, P.R.; Marek, S.M.; Melouk, H.A.; Garzon, C.D. Inferring the presence of aflatoxin-producing Aspergillus flavus strains using RNA sequencing and electronic probes as a transcriptomic screening tool. PLoS ONE 2018, 13, e0198575. [CrossRef] 
42. Lin, J.Q.; Zhao, X.X.; Zhi, Q.Q.; Zhao, M.; He, Z.M. Transcriptomic profiling of Aspergillus flavus in response to 5-azacytidine. Fungal Genet. Biol. 2013, 56, 78-86. [CrossRef]

43. Gao, C.; Jiang, B.; Wang, Y.; Liu, G.; Yang, C. Overexpression of a heat shock protein (ThHSP18.3) from Tamarix hispida confers stress tolerance to yeast. Mol. Biol. Rep. 2012, 39, 4889-4897. [CrossRef] [PubMed]

44. Whitley, D.; Goldberg, S.P.; Jordan, W.D. Heat shock proteins: A review of the molecular chaperones. J. Vasc. Surg. 1999, 29, 748-751. [CrossRef]

45. Singh, K.; Nizam, S.; Sinha, M.; Verma, P.K. Comparative transcriptome analysis of the necrotrophic fungus Ascochyta rabiei during oxidative stress: Insight for fungal survival in the host plant. PLoS ONE 2012, 7, e33128. [CrossRef] [PubMed]

46. Wang, S.; Zhou, H.; Wu, J.; Han, J.; Li, S.; Shao, S. Transcriptomic analysis reveals genes mediating salt tolerance through calcineurin/cchA-independent signaling in Aspergillus nidulans. BioMed Res. Int. 2017, 2017, 4378627. [CrossRef] [PubMed]

47. Yin, Z.; Stead, D.; Walker, J.; Selway, L.; Smith, D.A.; Brown, A.J.; Quinn, J. A proteomic analysis of the salt, cadmium and peroxide stress responses in Candida albicans and the role of the Hog1 stress-activated MAPK in regulating the stress-induced proteome. Proteomics 2009, 9, 4686-4703. [CrossRef]

48. Cowen, L.E.; Lindquist, S. Hsp90 potentiates the rapid evolution of new traits: Drug resistance in diverse fungi. Science 2005, 309, 2185-2189. [CrossRef] [PubMed]

49. Robbins, N.; Uppuluri, P.; Nett, J.; Rajendran, R.; Ramage, G.; Lopez-Ribot, J.L.; Andes, D.; Cowen, L.E. Hsp90 governs dispersion and drug resistance of fungal biofilms. PLoS Pathog. 2011, 7, e1002257. [CrossRef] [PubMed]

50. Cowen, L.E.; Singh, S.D.; Kohler, J.R.; Collins, C.; Zaas, A.K.; Schell, W.A.; Aziz, H.; Mylonakis, E.; Perfect, J.R.; Whitesell, L.; et al. Harnessing Hsp90 function as a powerful, broadly effective therapeutic strategy for fungal infectious disease. Proc. Natl. Acad. Sci. USA 2009, 106, 2818-2823. [CrossRef]

51. Burnie, J.P.; Matthews, R.C. Heat shock protein 88 and Aspergillus infection. J. Clin. Microbiol. 1991, 29, 2099-2106.

52. Kumar, A.; Reddy, L.V.; Sochanik, A.; Kurup, V.P. Isolation and characterization of a recombinant heat shock protein of Aspergillus fumigatus. J. Allergy Clin. Immunol. 1993, 91, 1024-1030. [CrossRef]

53. Blum, G.; Kainzner, B.; Grif, K.; Dietrich, H.; Zeiger, B.; Sonnweber, T.; Lass-Florl, C. In vitro and in vivo role of heat shock protein 90 in amphotericin B resistance of Aspergillus terreus. Clin. Microbiol. Infect. 2013, 19, 50-55. [CrossRef] [PubMed]

54. Lamoth, F.; Juvvadi, P.R.; Soderblom, E.J.; Moseley, M.A.; Asfaw, Y.G.; Steinbach, W.J. Identification of a key lysine residue in heat shock protein 90 required for azole and echinocandin resistance in Aspergillus fumigatus. Antimicrob. Agents Chemother. 2014, 58, 1889-1896. [CrossRef] [PubMed]

55. Lamoth, F.; Juvvadi, P.R.; Fortwendel, J.R.; Steinbach, W.J. Heat shock protein 90 is required for conidiation and cell wall integrity in Aspergillus fumigatus. Eukaryot. Cell 2012, 11, 1324-1332. [CrossRef] [PubMed]

56. Pratt, W.B. The Hsp90-based chaperone system: Involvement in signal transduction from a variety of hormone and growth factor receptors. Proc. Soc. Exp. Biol. Med. 1998, 217, 420-434. [CrossRef] [PubMed]

57. Blatzer, M.; Blum, G.; Jukic, E.; Posch, W.; Gruber, P.; Nagl, M.; Binder, U.; Maurer, E.; Sarg, B.; Lindner, H.; et al. Blocking Hsp70 enhances the efficiency of amphotericin B treatment against resistant Aspergillus terreus strains. Antimicrob. Agents Chemother. 2015, 59, 3778-3788. [CrossRef]

58. Lamoth, F.; Juvvadi, P.R.; Soderblom, E.J.; Moseley, M.A.; Steinbach, W.J. Hsp70 and the cochaperone StiA (Hop) orchestrate Hsp90-mediated caspofungin tolerance in Aspergillus fumigatus. Antimicrob. Agents Chemother. 2015, 59, 4727-4733. [CrossRef] [PubMed]

59. Haslbeck, M.; Braun, N.; Stromer, T.; Richter, B.; Model, N.; Weinkauf, S.; Buchner, J. Hsp42 is the general small heat shock protein in the cytosol of Saccharomyces cerevisiae. EMBO J. 2004, 23, 638-649. [CrossRef]

60. Li, J.; Qian, X.; Sha, B. Heat shock protein 40: Structural studies and their functional implications. Protein Pept. Lett. 2009, 16, 606-612. [CrossRef]

61. Tiwari, S.; Thakur, R.; Shankar, J. Role of heat-shock proteins in cellular function and in the biology of fungi. Biotechnol. Res. Int. 2015, 2015, 132635. [CrossRef]

62. Piper, P.W.; Ortiz-Calderon, C.; Holyoak, C.; Coote, P.; Cole, M. Hsp30, the integral plasma membrane heat shock protein of Saccharomyces cerevisiae, is a stress-inducible regulator of plasma membrane $\mathrm{H}^{+}$-ATPase. Cell Stress Chaperones 1997, 2, 12-24. [CrossRef] 
63. Seymour, I.J.; Piper, P.W. Stress induction of HSP30, the plasma membrane heat shock protein gene of Saccharomyces cerevisiae, appears not to use known stress-regulated transcription factors. Microbiology 1999, 145, 231-239. [CrossRef] [PubMed]

64. Montagna, G.N.; Buscaglia, C.A.; Münter, S.; Goosmann, C.; Frischknecht, F.; Brinkmann, V.; Matuschewski, K. Critical role for heat shock protein 20 (Hsp20) in migration of malarial sporozoites. J. Biol. Chem. 2012, 287, 2410-2422. [CrossRef] [PubMed]

65. Mayer, F.L.; Wilson, D.; Jacobsen, I.D.; Miramon, P.; Slesiona, S.; Bohovych, I.M.; Brown, A.J.; Hube, B. Small but crucial: The novel small heat shock protein Hsp21 mediates stress adaptation and virulence in Candida albicans. PLoS ONE 2012, 7, e38584. [CrossRef] [PubMed]

66. Amorós, M.; Estruch, F. Hsf1p and Msn2/4p cooperate in the expression of Saccharomyces cerevisiae genes Hsp26 and Hsp104 in a gene- and stress type-dependent manner. Mol. Microbiol. 2001, 39, 1523-1532. [CrossRef] [PubMed]

67. Sin, Y.Y.; Martin, T.P.; Wills, L.; Currie, S.; Baillie, G.S. Small heat shock protein 20 (Hsp20) facilitates nuclear import of protein kinase D 1 (PKD1) during cardiac hypertrophy. Cell Commun. Signal. 2015, 13, 16. [CrossRef] [PubMed]

68. Welker, S.; Rudolph, B.; Frenzel, E.; Hagn, F.; Liebisch, G.; Schmitz, G.; Scheuring, J.; Kerth, A.; Blume, A.; Weinkauf, S.; et al. Hsp12 is an intrinsically unstructured stress protein that folds upon membrane association and modulates membrane function. Mol. Cell 2010, 39, 507-520. [CrossRef] [PubMed]

69. Varela, J.C.; Praekelt, U.M.; Meacock, P.A.; Planta, R.J.; Mager, W.H. The Saccharomyces cerevisiae Hsp12 gene is activated by the high-osmolarity glycerol pathway and negatively regulated by protein kinase A. Mol. Cell. Biol. 1995, 15, 6232-6245. [CrossRef] [PubMed]

70. Ahn, J.; Won, M.; Choi, J.H.; Kyun, M.L.; Cho, H.S.; Park, H.M.; Kang, C.M.; Chung, K.S. Small heat-shock protein Hsp9 has dual functions in stress adaptation and stress-induced G2-M checkpoint regulation via Cdc25 inactivation in Schizosaccharomyces pombe. Biochem. Biophys. Res. Commun. 2012, 417, 613-618. [CrossRef] [PubMed]

71. Orlandi, I.; Cavadini, P.; Popolo, L.; Vai, M. Cloning, sequencing and regulation of a cDNA encoding a small heat-shock protein from Schizosaccharomyces pombe. Biochim. Biophys. Acta 1996, 1307, 129-131. [CrossRef]

72. Akbar, S.; Lee, S.Y.; Boylan, S.A.; Price, C.W. Two genes from Bacillus subtilis under the sole control of the general stress transcription factor $\sigma^{\mathrm{B}}$. Microbiology 1999, 145 Pt 5, 1069-1078. [CrossRef]

73. Gourion, B.; Francez-Charlot, A.; Vorholt, J.A. PhyR is involved in the general stress response of Methylobacterium extorquens AM1. J. Bacteriol. 2008, 190, 1027-1035. [CrossRef] [PubMed]

74. Han, D.; Link, H.; Liesack, W. Response of Methylocystis sp. strain SC2 to salt stress: Physiology, global transcriptome, and amino acid profiles. Appl. Environ. Microbiol. 2017, 83, e00866-17. [CrossRef] [PubMed]

75. Prágai, Z.; Harwood, C.R. Regulatory interactions between the Pho and $\sigma^{\mathrm{B}}$-dependent general stress regulons of Bacillus subtilis. Microbiology 2002, 148, 1593-1602. [CrossRef] [PubMed]

76. Morsy, M.R.; Almutairi, A.M.; Gibbons, J.; Yun, S.J.; de Los Reyes, B.G. The OsLti6 genes encoding low-molecular-weight membrane proteins are differentially expressed in rice cultivars with contrasting sensitivity to low temperature. Gene 2005, 344, 171-180. [CrossRef] [PubMed]

77. Medina, J.; Ballesteros, M.L.; Salinas, J. Phylogenetic and functional analysis of Arabidopsis RCI2 genes. J. Exp. Bot. 2007, 58, 4333-4346. [CrossRef]

78. Navarre, C.; Goffeau, A. Membrane hyperpolarization and salt sensitivity induced by deletion of PMP3, a highly conserved small protein of yeast plasma membrane. EMBO J. 2000, 19, 2515-2524. [CrossRef]

79. Wang, H.; Lei, Y.; Yan, L.; Cheng, K.; Dai, X.; Wan, L.; Guo, W.; Cheng, L.; Liao, B. Deep sequencing analysis of transcriptomes in Aspergillus flavus in response to resveratrol. BMC Microbiol. 2015, 15, 182. [CrossRef]

80. Bai, Y.; Wang, S.; Zhong, H.; Yang, Q.; Zhang, F.; Zhuang, Z.; Yuan, J.; Nie, X.; Wang, S. Integrative analyses reveal transcriptome-proteome correlation in biological pathways and secondary metabolism clusters in A. flavus in response to temperature. Sci. Rep. 2015, 5, 14582. [CrossRef]

81. Szilágyi, M.; Miskei, M.; Karányi, Z.; Lenkey, B.; Pócsi, I.; Emri, T. Transcriptome changes initiated by carbon starvation in Aspergillus nidulans. Microbiology 2013, 159, 176-190. [CrossRef]

82. Rockabrand, D.; Livers, K.; Austin, T.; Kaiser, R.; Jensen, D.; Burgess, R.; Blum, P. Roles of DnaK and RpoS in starvation-induced thermotolerance of Escherichia coli. J. Bacteriol. 1998, 180, 846-854.

83. Jenkins, D.E.; Auger, E.A.; Matin, A. Role of RpoH, a heat shock regulator protein, in Escherichia coli carbon starvation protein synthesis and survival. J. Bacteriol. 1991, 173, 1992-1996. [CrossRef] [PubMed] 
84. Spence, J.; Cegielska, A.; Georgopoulos, C. Role of Escherichia coli heat shock proteins DnaK and HtpG (C62.5) in response to nutritional deprivation. J. Bacteriol. 1990, 172, 7157-7166. [CrossRef] [PubMed]

85. Hahn, J.S.; Thiele, D.J. Activation of the Saccharomyces cerevisiae heat shock transcription factor under glucose starvation conditions by Snf1 protein kinase. J. Biol. Chem. 2004, 279, 5169-5176. [CrossRef] [PubMed]

86. Boender, L.G.; Almering, M.J.; Dijk, M.; van Maris, A.J.; de Winde, J.H.; Pronk, J.T.; Daran-Lapujade, P. Extreme calorie restriction and energy source starvation in Saccharomyces cerevisiae represent distinct physiological states. Biochim. Biophys. Acta 2011, 1813, 2133-2144. [CrossRef] [PubMed]

87. Abrashev, R.I.; Pashova, S.B.; Stefanova, L.N.; Vassilev, S.V.; Dolashka-Angelova, P.A.; Angelova, M.B. Heat-shock-induced oxidative stress and antioxidant response in Aspergillus niger 26. Can. J. Microbiol. 2008, 54, 977-983. [CrossRef]

88. Sugiyama, K.; Izawa, S.; Inoue, Y. The Yap1p-dependent induction of glutathione synthesis in heat shock response of Saccharomyces cerevisiae. J. Biol. Chem. 2000, 275, 15535-15540. [CrossRef] [PubMed]

89. Albrecht, D.; Guthke, R.; Brakhage, A.A.; Kniemeyer, O. Integrative analysis of the heat shock response in Aspergillus fumigatus. BMC Genom. 2010, 11, 32. [CrossRef]

90. Ogundero, V.W. Temperature and aflatoxin production by Aspergillus flavus and A. parasiticus strains from Nigerian groundnuts. J. Basic Microbiol. 1987, 27, 511-514.

91. Scheidegger, K.; Payne, G.A. Unlocking the secrets behind secondary metabolism: A review of Aspergillus flavus from pathogenicity to functional genomics. J. Toxicol. 2003, 22, 423-459. [CrossRef]

92. Lahouar, A.; Marin, S.; Crespo-Sempere, A.; Said, S.; Sanchis, V. Effects of temperature, water activity and incubation time on fungal growth and aflatoxin $\mathrm{B}_{1}$ production by toxinogenic Aspergillus flavus isolates on sorghum seeds. Rev. Argent. Microbiol. 2016, 48, 78-85. [CrossRef]

93. Staves, P.A.; Knell, R.J. Virulence and competitiveness: Testing the relationship during inter- and intraspecific mixed infections. Evolution 2010, 64, 2643-2652. [CrossRef] [PubMed]

94. Adler, P.B.; Smull, D.; Beard, K.H.; Choi, R.T.; Furniss, T.; Kulmatiski, A.; Meiners, J.M.; Tredennick, A.T.; Veblen, K.E. Competition and coexistence in plant communities: Intraspecific competition is stronger than interspecific competition. Ecol. Lett. 2018, 21, 1319-1329. [CrossRef] [PubMed]

(C) 2019 by the authors. Licensee MDPI, Basel, Switzerland. This article is an open access article distributed under the terms and conditions of the Creative Commons Attribution (CC BY) license (http://creativecommons.org/licenses/by/4.0/). 